\section{References}

Bindschadler, R. A., Zwally, H. J., Major, J. A. \& Brenner, A. C. 1989: Surface topography of the Greenland ice sheet from satellite radar altimetry. National Aeronautical and Space Administration, Special Publication SP-503, 105 pp. + 15 maps.

Blatter, H. 1987: On the thermal regime of an arctic valley glacier: a study of White Glacier, Axel Heiberg Island, N.W.T., Canada. J. Glaciol. 33(114), 200-211.

Braithwaite, R. J., Clement, P. \& Clausen, H. 1982: Inferences from a $19 \mathrm{~m}$ firn core, Nordbogletscher, South Greenland. Rapp. Grønlands geol. Unders. 110, 96-98.

Ohmura, A., Steffen, K., Blatter, H., Greuell, W. Rotach, M., Konzelmann, T., Laternser, M., Ouchi, A. \& Steiger, D. 1991: Energy and mass balance during the melt season at the equilibrium line altitude, Paakitsoq, Greenland ice sheet. Progress report No. 1, Department of Geography, ETH, Zürich, 108 pp.

Pfeffer, W. T., Illangasekare, T. H. \& Meier, M. F. 1991: Retention of Greenland runoff by refreezing: implications for projected future sea level change. $J$. geophys. Res. 96(C12), 22 117-22 124.

Polar Research Board (PRB), 1985: Glaciers, ice sheets and sea level: effect of a $\mathrm{CO}_{2}$-induced climatic change. Report of a workshop held in Seattle, Washington, September 13-15, 1984 prepared by the Polar Research Board, National Research Council, for the United States Department of Energy, Report no. DOE/EV/60235-1, 330 pp.

Thomsen, H. H., Olesen, O. B., Braithwaite, R. J. \& Weidick, A. 1989: Greenland ice-margin programme, a pilot study at Pâkitsoq, north-east of Jakobshavn, central West Greenland. Rapp. Grønlands geol. Unders. 145, 50-53.

Warrick, R., Oerlemans, J. 1990: Sea level rise. In Houghton, J. T., Jenkins, G. J. \& Ephraums, J. J. (ed.) Climate change - the IPCC scientific assessment, 257-281. Cambridge: Cambridge University Press.

Braithwaite, R. J. \& Olesen, O. B. 1990: Increased ablation at the margin of the Greenland ice sheet under a greenhouseeffect climate. Ann. Glaciol. 14, 20-22.

R. J. B., Geological Survey of Greenland, Copenhagen.

W. T. P., Institute of Arctic and Alpine Research, University of Colorado, Boulder, CO 80309-0450, USA.

H. B., Department of Geography, Swiss Federal Institute of Technology, Zürich, Winterthurerstrasse 190, CH-8057 Zürich, Switzerland.

N. F. H., Department of Geology and Geophysics, University of Wyoming, Laramie, WY 82071, USA.

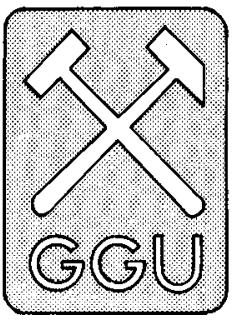

\title{
GGU's mineral resource activities and their role for the mineral industry
}

\author{
Hans K. Schønwandt
}

Increasing numbers of exploration companies are visiting the Geological Survey of Greenland's (GGU) headquarters in Copenhagen. A main reason for this was the announcement on 10th January 1991 by the Mineral Resources Administration for Greenland of a new policy to encourage exploration and exploitation of mineral resources in Greenland. Subsequently, new legislation replacing the previous mining law, was passed in June 1991. Some of the questions asked by visitors concern the relationship between the work areas of the industry and the role of the Survey. These questions focus on two of GGU's key functions: (1) the obligation to act as a data bank by collecting and compiling all types of geodata about Greenland; and (2) the active assessment of the mineral potential of Greenland by carrying out laboratory and field studies.

\section{Data presentation}

GGU archives form a data bank with a wide range of geodata from Greenland. As well as comprising data collected by GGU's own expeditions, the bank also contains exploration reports by commercial companies.

In recent years improved access to the information in GGU's archives has been obtained by establishing GREENMIN (the Greenland mineralisation data bank), publishing an Open File Series with the aim of presenting information to industry as quickly as possible, and by launching a Thematic Map Series including mineral occurrence maps (Schønwandt, 1990, 1991). The latter maps are also issued in other publications, e.g., in the Open File Series.

Each mineral occurrence in GREENMIN has a per- 


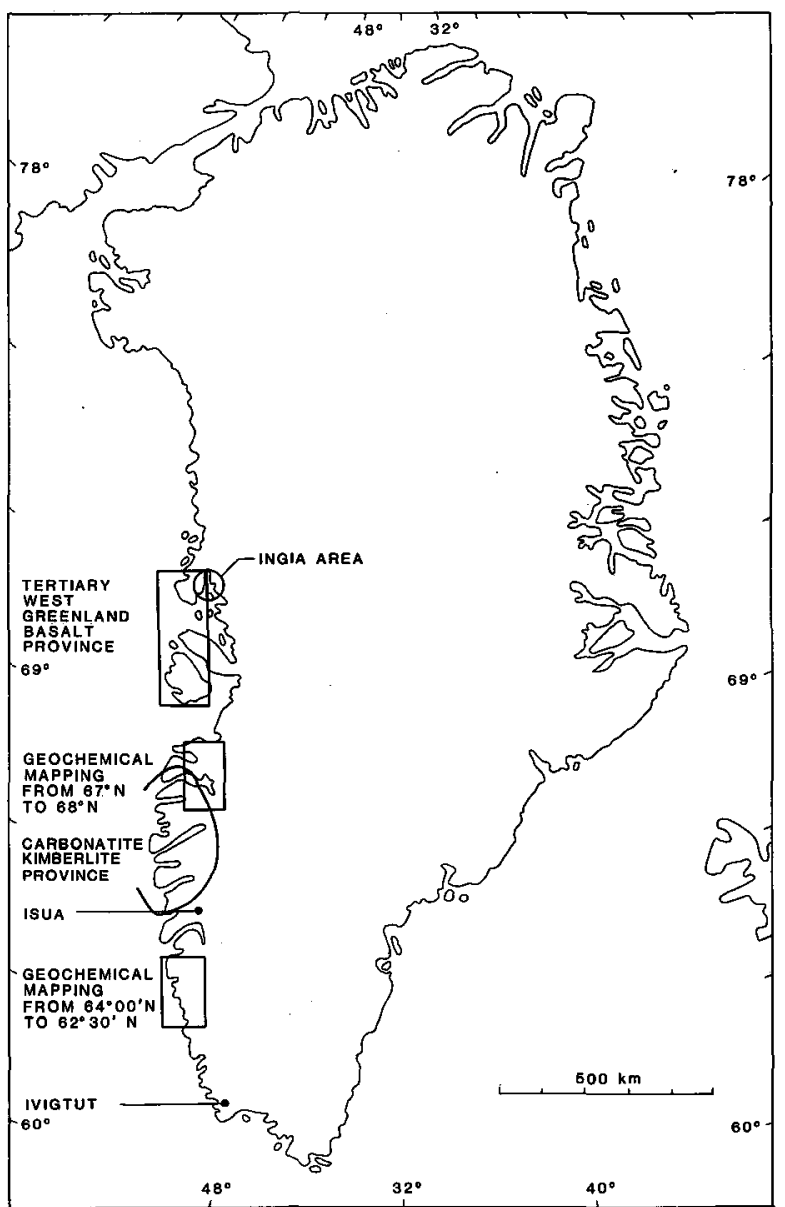

Fig. 1. Location map showing the areas pertaining to the Open File Series reports mentioned which have relevance to mineral exploration.

manent code number which correlates with the symbol for the mineralisation on the mineral occurrence maps. Any person studying these maps can by means of the code obtain a GREENMIN standard report on each mineralisation. The standard report includes a list of all available papers and unpublished reports that deal with that particular mineral occurrence.

The requirement of industry to acquire a quick summary of the exploration history and the geology of an area or a mineral deposit is met by the Open File Series.

In 1991 the Open File Series has included reports by Appel (1991) and Bondam (1991), reviewing the Isua iron ore deposit and the Ivigtut cryolite deposit respectively, whereas Ulff-Møller (1991) has discussed the mineral occurrences in the Tertiary West Greenland basalt province, and Thomassen (1991) the mineral potential of the lower Proterozoic supracrustal rocks of the Íngia area (Fig. 1). In addition, Larsen (1991) summar- ised the occurrences of kimberlite, lamproite and ultramafic lamprophyre in West Greenland and commented on their diamond potential.

\section{Assessment of mineral potential}

One of the Survey's major objects is to carry out assessment of the mineral potential of Greenland. So far exploration activity could be rightly said to have only locally scratched the surface, particularly when compared to other geologically equivalent areas in the world. The low level of exploration can best be illustrated by reference to the amount of diamond drilling: in the past 5 years only four mineral occurrences have been tested by drilling. Detailed knowledge of the mineral occurrences is therefore limited and this naturally influences the character of the assessment of the mineral potential of Greenland. A considerable part of the evaluation of the mineral potential is a modern geological appraisal of the Precambrian supracrustal belts of western Greenland (Dawes \& Schønwandt, 1992).

The first step in evaluation of the mineral potential of Greenland is the outlining of metallogenic provinces. A metallogenic province is in this context a region characterised by relatively abundant mineralisations of related types of deposits. The provinces will primarily be outlined on the basis of syntheses of tectono-stratigraphic units compared with geophysical and geochemical data. The Survey's own field activity in this connection is of a reconnaissance nature. In 1991 two reports were published in the Open File Series (Steenfelt \& Dam, 1991 and Erfurt et al., 1991), both reporting on reconnaissance geochemical investigations in West Greenland (Fig. 1).

The Survey's metallogenic programme also includes detailed studies of selected mineral occurrences with the aim of acquiring as complete an understanding of the mineralising processes as possible. In this way characteristics of ore deposit models can be included in the description of the metallogenic provinces and help industry to choose the most appropriate exploration guidelines.

The Survey's efforts are intended to stimulate and encourage industry to explore the mineral resources of Greenland - the Survey's metallogenic programme is part of that effort.

\section{References}

Appel, P. W. U. 1991: The Isua iron ore deposit at Isukasia, West Greenland. Open File Ser. Grønlands geol. Unders. 91/3, $31 \mathrm{pp}$. 
Bondam, J. 1991: The Ivigtut cryolite deposit in South Greenland. Short note on recent geoscientific developments. Open File Ser. Grønlands geol. Unders. 91/4, $29 \mathrm{pp}$.

Dawes, P. R. \& Schønwandt, H. K. 1992: Geological setting of Precambrian supracrustal belts: a fundamental part of mineral resource evaluation in Greenland. Rapp. Grønlands geol. Unders. 155 (this report).

Erfurt, P., Steenfelt, A. \& Dam, E. 1991: Reconnaissance geochemical mapping of southern West Greenland from $62^{\circ} 30^{\prime} \mathrm{N}$ to $64^{\circ} 00^{\prime} \mathrm{N}-1991$ results. Open File Ser. Grønlands geol. Unders. 91/9, $21 \mathrm{pp}$.

Larsen, L. M. 1991: Occurrences of kimberlite, lamproite and ultramafic lamprophyre in Greenland. Open File Ser. Grønlands geol. Unders. 91/2, $36 \mathrm{pp}$.

Schønwandt, H. K. 1990: Activities within the field of mineral resources. Rapp. Grønlands geol. Unders. 148, 37-40.
Schønwandt, H. K. 1991: Economic mineral resources: activities in 1990. Rapp. Grønlands geol. Unders. 152, 41-46.

Steenfelt, A. \& Dam, E. 1991: Reconnaissance geochemical exploration of map sheet $67 \mathrm{~V} .2\left(67^{\circ}\right.$ to $68^{\circ} \mathrm{N}, 49^{\circ} 30^{\prime}$ to $\left.52^{\circ} \mathrm{W}\right)$, West Greenland. Open File Ser. Grønlands geol. Unders. 91/8, 13 pp.

Thomassen, B. 1991: Gold and base metal potential of the Íngia area, central West Greenland. Open File Ser. Grønlands geol. Unders. 91/5, $115 \mathrm{pp}$.

Ulff-Møller, F. 1991: Magmatic platinum-nickel occurrences in the Tertiary West Greenland Basalt Province: prospecting by Greenex A/S in 1985-1988. Open File Ser. Grønlands geol. Unders. 91/1, $37 \mathrm{pp}$.

H. K. S., Geological Survey of Greenland, Copenhagen.

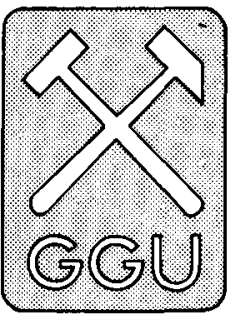

In Precambrian shield areas the economic potential of supracrustal rocks is well documented, and some of the world's largest metal deposits are found within these sequences. The Black Angel lead-zinc stratabound mineralisation at Mârmorilik in central West Greenland $\left(71^{\circ} 10^{\prime} \mathrm{N}\right.$, Fig. 1), hosted in the Proterozoic Karrat Group, is one commercial enterprise that confirms that this potential can be realised in Greenland. In last year's volume of Report of Activities, Thomassen (1991a) gave a history of the geology and mineral exploration of the Black Angel deposit.

The closure of the Black Angel mine in 1990 determined that Greenland entered the last decade of this century without an operative large-scale mining project. (The Ivigtut cryolite mine in South-West Greenland ceased on-site extraction in 1987.) Thus there is mounting expectancy that the exploration programmes presently being undertaken by commercial companies and those in the planning stage will lead to a fairly prompt resumption of the exploitation of Greenland's mineral resources.

\section{Geological setting of Precambrian supracrustal belts: a fundamental part of mineral resource evaluation in Greenland}

\author{
Peter R. Dawes and Hans K. Schønwandt
}

The relationship between the work areas of the commercial sector and the role of GGU with its wide range of short- and long-term scientific programmes has been outlined by Schønwandt (1992). More than ever before GGU's field programmes are designed at solving the geology of areas of economic importance, and GGU strives to assemble the sort of information that enables commercial enterprises to choose exploration targets.

This paper deals with one such programme: the mineral resource investigation of supracrustal belts of western Greenland.

\section{Data on supracrustal belts}

On GGU's geological maps of Greenland (sheets 1 to 5 at 1:500 000; see index map page 43 of this volume) supracrustal rocks in western Greenland are seen as patches and strips of green and brown within the very predominant red and orange colour of the gneiss complexes. The one exception is in the region between $71^{\circ}$ and $75^{\circ} \mathrm{N}$ where vast areas of the early Proterozoic 